\title{
FEDERAL CIVIL ACTION AGAINST PRIVATE INDIVIDUALS FOR CRIMES INVOLVING CIVIL RIGHTS
}

RACIAL violence by individuals and by private groups such as the Ku Klux Klan constitutes a serious obstacle to the Negro drive for equality. In order to assert their newly-won legal rights Negroes must be able to assemble and organize, free from violence. Federal protection of civil rights, however, is designed primarily to cope with violence and discrimination involving government participation or "state action,"1 not private violence or discrimination. The one exception is Section 241 of Title 18 of the United States Code which makes criminal conspiracies to deprive citizens of certain federal rights. ${ }^{2}$ Unfortunately, Section 241 has not been effective. Among the difficulties in applying this section are the requirement of specific intent ${ }^{3}$ and the reluctance of

1. See, e.g., 18 U.S.C. $\$ 242$ (1958) and 17 Stat. 13 (1871), 42 U.S.C. $\S 1983$ (1958), imposing criminal and civil liabilities, respectively, on any person who deprives another of his civil rights "under color of" state or local law or custom.

2. If two or more persons conspire to injure, oppress, threaten, or intimidate any citizen in the free exercise or enjoyment of any right or privilege secured to him by the Constitution or laws of the United States, or because of his having so exercised the same; or

If two or more persons go in disguise on the highway, or on the premises of another, with intent to prevent or hinder his free exercise or enjoyment of any right or privilege so secured -

They shall be fined not more than $\$ 5,000$ or imprisoned not more than ten years, or both.

Rev. Stat. § 5508 (1875), 18 U.S.C. \& 241 (1958).

Section 241 has been held to protect those rights "which arise from the relationship of the individual and the Federal Government" and which "flow from the substantive powers" of that government. United States v. Williams, 341 U.S. 70, 77, 78 (1951). Among such rights are:

the right to vote for federal officials, Ex parte Yarbrough, 110 U.S. 651 (1884);

the right to enjoy privileges under the homestead laws, United States v. Wacldell, 112 U.S. 76 (1884);

the right to protection while in the custody of a federal officer, Logan v. United States, 144 U.S. 263 (1892) ;

the right to inform federal officials of violations of federal laws, In re Quarles, 158 U.S. 532 (1895) ;

the right to testify before a federal agency, Foss v. United States, 266 Fed. 881 (9th Cir. 1920).

Other rights of "national" citizenship, presumably protected by $\S 241$, include the right of assembly for national purposes, United States v. Crinkshank, 92 U.S. 542 (1875) (dictum), Hague v. CIO, 307 U.S. 496 (1939), and the right to travel from state to state, Crandall v. Nevada, 73 U.S. (6 Wall.) 35 (1867) ; Edwards v. California, 314 U.S. 160, 177 (concurring opinion) (1941). See discussion in United States v. Williams, 341 U.S. 70 (1951).

3. The prevailing interpretation of $\S 241$ is that given in Screws v. United States, 325 U.S. 91 (1945), in which the Court required that, to sustain a federal conviction under $\$ 241$, the offender must have "a specific intent to deprive a person of a federal right made definite by decision or other rule of law." Id. at 103. The offender must have 
southern juries to convict. As a consequence of these difficulties, and because of the Justice Department's reluctance to prosecute unless there is a probability of conviction, ${ }^{4}$ there have been few prosecutions. State law is equally ineffective in coping with private violence. Community pressures upon state and local prosecutors often prevent them from prosecuting in any but the most widely publicized racial crimes. Even when publicity from "outside" forces a prosecution, local juries often refuse to convict. Short of new legislation, increased protection of civil rights from private violence must come from the possible reinterpretation and expansion of existing statutes. This Note explores one possibility: a federal civil action against private individuals.

Section 1985(3) of Title 42 of the United States Code provides, in part:

If two or more persons in any State or Territory conspire or go in disguise on the highway ... for the purpose of depriving, either directly or indirectly, any person or class of persons of the equal protection of the laws, or of equal privileges and immunities under the laws .....

... If one or more persons engaged therein do, or cause to be done, any act in furtherance of the object of such conspiracy, whereby another is injured in his person or property, or deprived of having and exercising any right or privilege of a citizen of the United States, the party so injured or deprived may have an action for the recovery of damages, occasioned by such injury or deprivation, against any one or more of the conspirators. ${ }^{5}$

As a civil action for damages, Section 1985(3) would have advantages over Section 241, its criminal counterpart. First, control over initiation of the suit would rest with the party rather than with the prosecutor. Admittedly, the desirability of party control is subject to argument. In recent years the Justice Department has been reluctant to initiate criminal prosecutions under Section 241 because the Department felt that a large number of unsuccessful prosecutions would generate contempt for the civil rights statutes. ${ }^{\circ}$ But complete failure to implement existing legislation is likely to generate even more contempt for the law than would unsuccessful prosecutions. And even unsuccessful lawsuits may have an educative and therapeutic effect upon the community by publicizing lawless conduct. Perhaps such publicity would stir responsible southerners to curb the violence of lawless elements in their own community. In addition, prosecutions or civil suits which fail because of defects in our present judicial system - for example, the failure of all-white juries to convict, traceable in part to discriminatory selection procedures 7 - are important

known or should have known that he was depriving his victim of a constitutional right. This requirement has led to great confusion in the minds of judges, jurors and litigants alike. Recent attempts by the Department of Justice to obtain a clarification have failed. See 1961 United States Connr'N on Civil Rights Report (Book 5), 45-52.

4. Id. at 63. Another related problem is that United States Attorneys are sometimes more responsive to local pressures than to directions from Washington. Id. at 64 .

5. Rev. Stat. § 1980(3) (1875), 42 U.S.C. § 1985(3) (1958).

6. See 1961 United States Coan'N on Civil Rignts Report (Bools 5), 63.

7. Id., ch. 7 . 
in focusing attention on these defects and on the need for reform. Finally, litigation forces the offender to prepare and pay for a legal defense; he must hire counsel, submit to discovery, appear in court, and perhaps have his property attached. It may be that the "nuisance" value of the litigation constitutes an effective deterrent to private violence. ${ }^{8}$ As long as the Justice Department continues to use the probability of conviction standard, party control of the suit is desirable. ${ }^{9}$ Second, unlike a criminal prosecution, no specific intent need be proved under Section 1985 (3). ${ }^{10}$ The elimination of this requirement considerably enhances the chances of success in the civil action. And, third, the civil nature of Section 1985(3) should ease the problem of obtaining relief from those southern juries which are biased. Juries may be more willing to exact damages from a defendant than subject him to a prison sentence and the stigma of a criminal conviction. ${ }^{11}$

However desirable Section 1985 (3) may seem as an additional legal deterrent to racial violence, the Supreme Court decision in Collins v. Hardyman ${ }^{12}$ presents a serious stumbling block to its effective use. The rights protected by 1985 (3), in part, are defined as the right to be free of conspiracies whose purpose is to deprive any person "of the equal protection of the laws, or of equal privileges and immunities under the laws." This definition is capable of a broad interpretation and seemingly could afford protection against private violence. However, the Supreme Court in the Collins case interpreted the clause restrictively and, in effect, confined its application to instances involving "state action" or the complete breakdown of state law enforcement.

Collins involved members of a Los Angeles Democratic Club who held a meeting to discuss a proposal condemning the Marshall Plan. The Club in-

8. It is assumed that groundless suits would not be brought merely for harassment purposes. State law could supply adequate protection against such conduct.

9. The United States Commission on Civil Rights has criticized the Justice Department for attaching exclusive value to the "success" factor. 1961 United States Comu'N oN Crvil Rights RePort (Book 5), 63. For a more detailed criticism of the probability of conviction standard and discussion of the need for more lawsuits, see Note, 74 Y ALE L.J. 1297 (1965).

10. In construing 42 U.S.C. $\$ 1983$, a civil remedy directed toward state action that is similar to $\S 1985(3)$, the Supreme Court noted the absence of any requirement of "wilfulness" in that statute and held that no specific intent need be proved to sustain n civil claim. The Court stated that the section "should be read against the background of tort liability that makes a man responsible for the natural consequences of his actions." Monroe v. Pape, 365 U.S. 167, 187 (1961). Compare the treatment of "specific intent" in Screws v. United States, supra note 2.

11. In many instances a civil action will accomplish results when a criminal prosecttion will not, because a jury which might be reluctant to convict a defendant in a criminal prosecution for a violation of civil rights might not hesitate to afforl relief in the form of a civil penalty.

To Secure These Rights, Report of the President's Comm, on Crvil Ruguts 130 (1947). See also Schweinhaut, The Civil Liberties Section of the Department of Justice, 1 Brus of Rights REv. 206, 216 (1941).

12. 341 U.S. 651 (1951). 
tended to forward its condemnation, in the form of a petition for the redress of grievances, to the appropriate federal officials. The defendants, members of the American Legion, used force to break up the meeting. Plaintiffs sued under 1985(3) alleging that the Legionnaires had conspired for the purpose of depriving plaintiffs of equal privileges and immunities by depriving them of their right to assemble and petition the government. The District Court granted defendants' motion to dismiss ${ }^{13}$ on the ground that the complaint failed to show "state action." The Court of Appeals reversed, ${ }^{14}$ holding that no showing of "state action" was necessary. The Supreme Court, in an opinion by Justice Jackson, affirmed the District Court's dismissal of the complaint.

Justice Jackson, in analyzing Section 1985(3) declared that it fell into two parts: the first defining punishable conspiracies and the second describing the overt acts required to make the conspiracy actionable. He assumed, without deciding, that plaintiffs met the overt act requirement because they had been deprived of "having and exercising a federal right." But the overt act must be in furtherance of the "very limited" conspiracies defined in the act. These conspiracies must be

for the purpose of depriving ... [any person] of the equal protection of the laws, or of equal privileges and immunities under the law. ${ }^{10}$

Justice Jackson then argued that the conspiracies defined by Section 1985(3) included the element of state action:

The only inequality suggested is that the defendants broke up plaintiffs' meeting and did not break up meetings of others with whose sentiments they agreed. To be sure, this is not equal injury, but it is no more a deprivation of "equal protection" or of "equal privileges and immunities" than it would be for one to assault one neighbor without assaulting them all. ... Such private discrimination is not incquality before the law unless there is some manipulation of the law or its agcncies to give sanction or sanctuary for doing so. Plaintiffs' rights were certainly invaded, disregarded and lawlessly violated, but neither their rights nor their equality of rights under the law have been, or were intended to be, denied or impaired. ${ }^{17}$

Jackson conceded that some private conspiracies could be of such magnitude as to come within the statute:

We do not say that no conspiracy by private individuals could be of such magnitude and effect as to work a deprivation of equal protection of the laws or equal privileges and immunities under laws. Indeed, the postCivil War Ku Klux Klan . . . was able effectively to deprive Negroes of

13. Hardyman v. Collins, 80 F. Supp. 501 (S.D. Cal. 1948).

14. Hardyman v. Collins, 183 F.2d 308 (9th Cir. 1950).

-15. 341 U.S. at 660 .

16. Ibid. (Emphasis in original.)

17. Although he did not base the decision upon it, Jackson also noted "in passing" the argument derived from the Civil Rights Cases, 109 U.S. 3 (1883), that an individual cannot deprive anyone of his constitutional rights, though he may invade or violate those rights. Id. at 661 (Emphasis added). 
their legal rights and to close all avenues of redress or vindication ... But here nothing of that sort appears. We have a case of lawless political brawl, precipitated by a handful of white citizens against other white citizens. California courts are open to plaintiffs and its laws offer redress for their injury and vindication for their rights. ${ }^{18}$

And he concluded that:

We say nothing of the power of Congress to authorize such Civil actions as respondents have commenced or otherwise to redress such grievances as they assert. We think that Congress has not, in the narrow class of conspiracies defined by this statute, included the conspiracy charged here. ${ }^{10}$

The opinion fails to satisfy inquiry. The essence of Jackson's argument is that while Congress may give a right of action against individuals who conspire to interfere with certain federal rights, it did not do so because, as the lower District Court more succinctly stated, "[T] he qualifying word 'cqual' [in the statute] presupposes state action."20 But this reasoning is purely conceptual. Although it is certainly tenable to construe the words of the statite to mean "state action," such a construction is by no means compelled. The words "equal protection" of the laws or "equal privileges and immunities" are, after all, abstract. The Court of Appeals and the dissent in Collins read these words to reach private action. ${ }^{21}$ And in United States $v$. Harris, ${ }^{22}$ the Supreme Court construed identical language as directed "exclusively against the action of private persons, without reference to the laws of the State, or their administration by its officers. ..." Since the language alone could lead to either conclusion the failure of the Court in Collins to make any inquiry into the legislative history of Section 1985(3) is disappointing. In fact, the inquiry would have revealed that the statute was aimed at acts of private individuals as well as public officials.

18. Id. at 662 .

19. Ibid.

20. 80 F. Supp. at 506 .

21. The language of the statute refutes the suggestion that action under color of state law is a necessary ingredient of the cause of action which it recognizes.

R.S. $\S 1980$ (3) speaks of "two or more persons in any State or Territory" conspiring. That clause is not limited to state officials. Still more obviously where the section speaks of persons going "in disguise upon the highway ... for the purpose of depriving . . . any person or class of persons of the equal protection of the laws," it certainly does not limit its reference to actions of that kind by state officinls. When Congress, at this period, did intend to limit comparable civil rights legislation to action under color of state law, it said so in unmistakable terms. In fact, R.S. $\$ 1980$ (3) originally was $\S 2$ of the Act of April 20, 1871, and $\$ 1$ of that same Act said "That any person who, under color of any laze . . . subject[s] . . . any person .... to the deprivation of any rights, ... secured by the Constitution of the United States, shall . . . be liable to the party injured. . . ." (emphasis added) 17 Stat. 13.

341 U.S. at 663-64 (Burton, J. dissenting). See also Collins v. Hardyman, 183 F.2d 308, 311-12 (9th Cir. 1950), rev'd, 341 U.S. 651 (1951).

22. 106 U.S. 629,640 (1882). 
Section 1985(3) was enacted in reaction to the wave of Klan terror then sweeping the South. 23 As introduced, the bill did not speak in terms of "equal" protection or "equal" privileges and immunities:

If two or more persons shall, ... conspire, or combine together to do any act in violation of the rights, privileges, or immmunities of any person, to which he is entitled under the Constitution and laws of the United States, which, committed within a place under the sole and exclusive jurisdiction of the United States, would under any law of the United States then in force, constitute the crime of either murder, manslaughter, mayhem, robbery, assault and battery ... : [they] . . . shall be . . guilty of a felony.2 The amendment that added the qualifying word "equal" (and also the civil damage provisions) came later, as an artful compromise between three different groups. Each of these groups agreed that the legislation should reach private action, but differed in the scope of the conduct they wished to prohibit.

The first group wanted to protect these rights of federal citizenship arising out of the relationship between the citizens and the federal government and which flow from the inherent powers and existence of the federal government. ${ }^{25}$ This group distinguished these rights from rights the Constitution merely guaranteed against state infringement under the fourteenth amendment. Presumably, Congress could protect the former rights against private infringement. ${ }^{26}$ The distinction between these two sets of rights has been developed subsequent to the debates. ${ }^{27}$ Such rights of federal citizenship include, among others, the right to pass freely from state to state, the right to petition Congress for a redress of grievances, the right to vote for national officers, and the right to be protected against violence while in the lawful custody of a - United States Marshall. ${ }^{28}$ At the time section 1985(3) was debated, though, these rights had not yet been judicially established, ${ }^{29}$ and it is not clear what Congress thought were the rights of national citizenship. ${ }^{30}$ The debates suggest,

23. Section 1985(3) was originally part of the Ku Klux Act of April 20, 1871. 17 Stat. 13 (1871).

24. Cong. Grobe, $42 d$ Cong., 1st Sess. 317 (1871) (emphasis added) (hereinafter cited as GIOBE).

25. It appears that those members of Congress who believed they were protecting national rights fell into two sub-groups: those who believed that the provision of the fourteenth amendment declaring "all persons born or naturalized in the United States are citizens thereof" gave Congress power to directly protect national rights, and those who believed Congress could protect the rights of national citizenship without relying on the fourteenth amendment. For the views of the former see GLOBE, 475-76 (Remarks of Rep. Dawes); Id., Appendix, 83-85 (Remarks of Rep. Bingham). For the views of the latter, see $I d$. at 382-83 (Remarks of. Rep. Hawley). The floor leader, Rep. Shellabarger, equivocated between the two positions. Id. at 382, 478, Appendix at 69.

26. See debates cited note 25 supro.

27. Cf. Slaughter-House Cases, 83 U.S. (16 Wall.) 36 (1872).

28. See cases cited at note 2 supra.

29. Except for Crandall v. Nevada, 73 U.S. (6 Wall.) 35 (1867).

30. Examples of national rights that were cited during the debates included:

The right to travel interstate; the right to express opinions on "all subjects which are not against the good order of the Government"; "a right to have his [a citizen's] 
though, that the members of the first group believed the rights to be broader ${ }^{81}$ than the Supreme Court's narrow interpretation in the Slanghter House Cases $^{32}$ and in subsequent cases. ${ }^{33}$

The second group went further than the first by arguing that Congress should legislate directly against individual deprivation of fourteenth amendment rights when anarchy rendered the state helpless to enforce its own laws. ${ }^{34}$ In these situations, the state denied the individual "rights, privileges, and immunities" under the fourteenth amendment. The third group argued for an even broader extension of federal power. They would have effectively displaced state authority over law enforcement, asserting that the fourteenth amenclment empowered Congress to set up a supervening federal jurisdiction over the acts of individuals. ${ }^{35}$ The position of this last group presented difficulties for the floor manager of the bill. Some of the sympathetic Republicans objected to the bill as introduced because they feared that it embodied the views of this group. By enumerating the specific crimes that could be punished if done "in violation of the rights, privileges, and immunities" of an individual, the bill's effect would be to "extend the [United States] criminal code over all the States of this Union." 36

The sponsors of the bill therefore, amended the language with three ends in mind. To accommodate all three factions, ${ }^{37}$ the floor leader had to protect the "fundamental" rights of national citizenship. At the insistence of the second and third groups, they had to frame the amendment in such a way that fourteenth amendment rights would be protected in cases of complete state breakdown. And finally, to answer the supporters' objections, they had to do both in language that would not completely override state enforcement of its laws.

Introducing the amendment, Representative Shellabarger, the floor leader, explained cryptically why the qualifying word "equal" had been added:

The change which the amendment proposes to make in section two of the original bill as reported by the committee, so far as it relates to disputed grounds, so far as it is not confined to infractions of right which arc clcarly

case tried within a United States Federal court [which] has jurisdiction"; and a right to support and advocate the election of any qualified person to any [federal] office. GLopt, 382 (remarks of Rep. Hawley); Id. at 486 (remarks of Rep. Cook).

31. Debates cited note 25 supra. Some Congressmen, who talked in terms of the "rights, privileges, and immunities of the American citizen," envisaged them as includint the Bill of Rights. See, e.g., Id. at 475 (remarks of Rep. Dawes).

32. Note 28 stipra.

33. See note 3 supra.

34. GLOBE, 607-08 (remarks of Rep. Pool); Id. at 485 (remarks of Rep. Cook). The debates suggest that the second group agreed with the first that Congress could also protect, in stable as well as in "anarchic" periods, the rights of "national citizenship." Id. at 485-87 (remarks of Rep. Cook); in any event, when Rep. Shellabarger introduced the compromise amendment (see note 37 infra) he was bidding for support from both groups. Id. at 478.

35. Id. at 334 (remarks of Rep. Hoar) ; id. at 487 (remarks of Rep. Tyner).

36. Id. at 382 .

37. See note 35 supra. 
independent of the 14th anendnent, referable to and clcarly sustainable by the old provisions of the Constitution, is to be found in those portions of the section which are contained in the part beginning at line twentyfive, I think. ...

The object of the amendment is ... to confine the authority of this law to the prevention of deprivations which attack the equality of rights of American citizens; that any violation of the right, the animus and effect of which is to strike down the citizen, to the end that he may not enjoy equality of rights as contrasted with his and other citizens' rights shall be within the scope of the remedies of this section. ${ }^{38}$

Shellabarger's is an explicit statement that, in changing the wording of the clause to "equal," there was no intent to exclude protection of the rights of national citizenship. These rights are "clearly independent of the 14th amendment, referable and clearly sustainable by the old provisions of the Constitution." The change related to the "disputed grounds." Since all proponents agreed that the rights incident to national citizenship could and should be protected, the "disputed grounds" can only refer to the division of opinion regarding the extent of protection Congress could otherwise constitutionally afford under the fourteenth amendment. Regarding the scope of protection of these rights, the qualifying word "equal" was added to "confine the authority of this law to the prevention of deprivations which attack the equality of rights of American citizens."

The legislative history does not support Jackson's argument in Collins that section 1985(3) reaches only conspiracies which dominate the state government. ${ }^{39}$ Certainly all of the bill's proponents supported this result. But this argument misconceives the nature of the congressional compromise. The addition of the word "equal" was a term of limitation only in the sense that Congress wished to avoid subverting the entire criminal jurisdiction of the states. However, within the confines of this limitation, Congress wished to act to the full extent of its constitutional power in order to satisfy the Radical Republicans. Consequently, the somewhat vague references $\$ 0$ to the rights "clearly independent of the fourteenth amendment" and the "equality of rights of American citizens" - allusions to national rights of federal citizenship - are terms of expansion. However vague an exercise of congressional power this may be, as a product of political bargaining, the compromise furnishes guidelines for an interpretation of 1985(3).

Justice Jackson's interpretation of 1985(3) appears too restrictive because it ignores the expansive element in Congress' intent. A construction of 1985 (3) which includes not only situations of anarchy, but which also protects fundamental rights of national citizenship, appears more consistent with the congres-

38. GLOBE, $4 / 78$ (emphasis added). It is clear that Shellabarger, pointing at the changed language, is referring to the portion concerning "equal protection and equal privileges and immunities," because that is the only portion of the amendment that bears any relation to the original Section 2.

39. See note 19 supra and accompanying text. The statutory construction argument of the dissenters in Collins, see note 22 supra, does not fully meet this argument of Jaclison's.

40. See Remarks of Rep. Shellaberger, text accompanying note 39 supra. 
sional compromise. Justice Jackson sought a narrow construction of 1985(3), apparently to avoid "constitutional problems of the first magnitude ... [ [including] Congressional power under and apart from the fourteenth amendment, the reserved power of the states, the content of rights derived from national as distinguished from state citizenship." ${ }^{41}$ But national rights have been defined narrowly through the application of Section 241 in the course of nearly a hundred years. ${ }^{42}$

It might still be argued, however, that because the rights protected under Section 241 remain somewhat unclear ${ }^{43}$ and thus are potentially of mutch broader scope, to allow a civil action may have the result of flooding the federal courts with suits that should be left to the states. To be sure, unless the rights protected under Section 1985(3) are of broad enough scope to protect the main thrust of Negro organizational activity such as voter education classes, mass meetings, and door to door canvassing, the statute will be of limited utility. Existing law suggests that this type of organizational activity could come under the category of a national right. In ex parte Yarbrough, ${ }^{44}$ the Supreme Court stated that the federal government "must have the power to protect the elections on which its existence depends from violence and corruption." The rationale of Yarbrongh indicates that congressional power over voting, though limited to federal elections, extends to voter registration activity. ${ }^{45} \mathrm{~A}$ long line of cases implies that Congress may also protect the right of

41. Collins v. Hardyman, 341 U.S. 651, 659 (1951).

42. See notes 3 and 28 supra.

43. See 1 Earerson \& Haber, Political and Civil Rights in the United States 74-79 (2d ed. 1958).

44. 110 U.S. 651,658 (1884).

45. The plaintiff in Yarbrough was a qualified voter. But the rationale of the decision does not depend on his status. The court emphasized that the source of the power to protect the voter arises by necessity; a government whose power depends upon the consent of the governed has a duty to ensure

that he may exercise this right freely, and to protect him from violence while so doing .... This duty does not arise solely from the interest of the party conlcerned, but from the necessity of the government itself, that its service shall be free from the adverse influence of force and fraud practiced on its agents, and that the votes by which its members of Congress and its President are elected shall be the free votes of the electors. . . .

Id. at 662 (Emphasis in original).

Thus, the legal status of the claimant (be he registered or unregistered) should not determine the extent of the protection: it is the political process which must be protected. Since registration is a necessary prerequisite to voting status, protection of the registration process is essential to a healthy body politic, deserving of the same protection as the right to vote.

Protection from violent interference with the right to register is only a small extension of the holding in Yarbrough. The harder question is the extent of the activity which can be fairly characterized as "registration." Do voter registration workers have a right to be free from violence while encouraging others to register? Are voter education classes, mass meetings and the like part of the registration process? Under Yarbrongh, the answer' 
"its citizens to meet peaceably for consultation in respect to public affairs and to petition for a redress of grievances," 46 that is, the right of "speaking and printing on subjects relating to [the national] government."47 Since the discussion at many mass meetings and gatherings connected with the Negro civil rights movement invariably includes federal legislation of one kind or another, 1985(3) may provide a damage claim for violent interference with these meetings.

Despite the fact that national rights may be interpreted broadly, Section 1985(3) should still be applied. An argument to the contrary ignores the fact that some states seem unwilling to provide redress for the deprivation of federal rights, particularly the rights of activist groups in the civil rights movement. Also if there is a flood of actions under 1985(3) which upsets the federal balance, Congress may always take remedial action. IVith these two points in mind, the courts should be unwilling to vitiate a statute whose authors intended to protect federal rights against individual violence.

would depend on what effect violent interference with the particular activity has on the freedom of the political process; if it can be shown that the violence proximately interferes with the expression of the will of the people, the Yarbrough rationale calls for protection from the violence. In United States v. Wood, 295 F.2d 772 (5th Cir. 1961), cerl. denied, 369 U.S. 850 (1962), the Court of Appeals granted the federal government's request to enjoin a state criminal proceeding brought against a voter registration worker for the purpose of intimidating Negroes who were attempting to register. Despite the general policy limiting federal court enjoinment of state proceedings in order to avoid conflict between the systems, the court held that voter registration activity was sufficiently related to the free political process to deserve the same protection from irreparable injury as the right to vote.

For the interesting claim that Yarbrough extends congressional power to state elections as well as federal elections, see Note, 74 YaLE L.J. 1448 (1965).

46. United States v. Cruikshank, 92 U.S. 542, 552 (1875).

47. Powe v. United States, 109 F.2d 147, 151 (5th Cir. 1940), cert. denied, 309 U.S. 679 (1940). See also Hague v. CIO, 307 U.S. 496, 513 (1939); In re Quarles, 158 U.S. 532, 535 (1895) ; Presser v. Minois, 116 U.S. 252, 267 (1886). 